\title{
Curie per Kilogram
}

National Cancer Institute

\section{Source}

National Cancer Institute. Curie per Kilogram. NCI Thesaurus. Code C70529.

A unit of specific radioactivity (massic activity) equal to activity of one Curie of the sample with total mass of one kilogram. 